УДК 342.9

DOI https://doi.org/10.32837/pyuv.v2i3(28).366

C. С. Мусаєва

ад’юнкт

Одеського державного університету внутрішніх справ

O.M. $3 a \epsilon u b$

кандидат юридичних наук, доцент,

професор кафедри криміналістики та психології

Одеського державного університету внутрішніх справ

\title{
ПИТАННЯ ПРОТИДІЇ ВУЛИЧНІЙ ЗЛОЧИННОСТІ ТА ПІДВИЩЕННЯ РІВНЯ ПУБЛІЧНОГО ПОРЯДКУ І БЕЗПЕКИ НА ТЕРИТОРІЇ ОДЕСЬКОЇ ОБЛАСТІ
}

Питання злочинності в кожній країні, зокрема i в нашій державі, було і залишається актуальним. Вулична злочинність завжди турбувала громадськість і викликала негативні реакції населення. Кожен житель нашої держави і регіону має страх стати жертвою вуличних злочинців, тому посилюється психологічне напруження в районі, місті, області та в країні в цілому.

Регламентація та реалізація заходів запобігання та протидії вуличній злочинності, а також забезпечення та підвищення рівня публічної безпеки є вагомими проблемами, що потребують негайного вирішення. Саме протидія вуличній злочинності та забезпечення рівня безпеки громадян є пріоритетними напрямами діяльності органів поліції.

Велика стурбованість через вчинення вуличної злочинності виникає у зв'язку із їі масовістю. Зазначені злочини здебільшого вчиняються раптово, в темну пору доби, переважно у великих населених пунктах із великою щільністю населення. Значна кількість правопорушень даної категорії вчиняється групами осіб, особами, які перебувають в алкогольному або ж наркотичному сп'янінні.

Виокремлення категорії злочинів, вчинених у громадських місцях, як самостійного виду правопорушень було здійснене як у кримінологічній науці, так і на практиці. Різні аспекти цієї злочинності висвітлювались у працях таких науковців, як В.М. Дрьомін, О.М. Джужа, В.В. Василевич, О.Г. Кулик, Д.В. Петров, В.І. Шакун.

Метою статті $€$ розкриття поняття вуличної злочинності, виявлення причин та умов, що їй спряють, та здійснення аналізу об'єктивних i суб'єктивних факторів, що впливають на стан публічної безпеки і порядку на території оперативного обслуговування Одеської області.

Більшість вуличних насильницьких і майнових злочинів вчиняється в умовах темного часу доби, що суттєво ускладнює їх розкриття та покарання винних.

Визначення вулиці дається у Положенні про порядок ведення Єдиного реєстру досудових роз- слідувань, затвердженому Наказом Генеральної прокуратури України від 06.04.2016 року № 139, яке визначає порядок включення до Реєстру кримінальних правопорушень, що були вчинені на вулицях, площах, у парках, скверах. Так, у підпункті 23 пункту 2 розділу II зазначеного Положення сказано, що вулицею вважається відкрита частина території міста чи населеного пункту (крім приміщень та будівель), на якій перебувають громадяни, рухається транспорт, до якої є вільний доступ у будь-яку пору року та час доби.

Відповідно до підпункту 24 пункту 2 розділу II Положення до кримінальних правопорушень, вчинених в умовах вулиці, належать такі діяння: крадіжки з ресторанів, кафе, закладів громадського харчування, магазинів, кіосків, транспортних засобів, інших об'єктів, якщо проникнення в них було здійснене безпосередньо з вулиці; незаконні заволодіння транспортними засобами, якщо вони перебували на вулиці, біля будинків, на стоянках, які не охороняються [1].

Поточна криміногенна обстановка на території Одеської області зумовлюється складною політичною, економічною та соціальною ситуацією, яка склалася в нашій державі та у цьому регіоні протягом останніх років. Крім цього, на стан публічної безпеки та порядку значно впливає географічне розташування та наявність значної кількості соціально-етнічних меншин.

Проаналізувавши злочини, скоєні на вулицях та в інших публічних місцях за останні три роки (2017, 2018 та 9 місяців 2019 року), ми дійшли висновку, що завдяки вжитим правоохоронними органами заходам вдалося дещо поліпшити стан криміногенної ситуації в публічних місцях.

Так, згідно зі статистичними даними на території Одеської області у 2017 році всього було зареєстровано 30887 кримінальних правопорушень, з яких було розкрито 13007 , що становить $42,2 \%$. У публічних місцях у 2017 році було скоєно 3191 кримінальне правопорушення, що становить $10,33 \%$ від загальної кількості вчинених злочинів, з яких було розкрито 1680 , тобто $52,6 \%$. 
У 2018 році на території Одеської області всього було скоєно 1410 кримінальних правопорушень, що становить $5,05 \%$ від загальної кількості вчинених правопорушень, з яких було розкрито 719 , тобто $52,6 \%$. Порівняно з 2017 роком зниження злочинів, вчинених в публічних місцях, становить $55,8 \%$.

За 9 місяців 2019 року на території Одеської області всього було зареєстровано 18382 кримінальних правопорушення, з яких було розкрито 5633 , що становить $30,6 \%$. Порівняно із аналогічним періодом 2018 року зниження загальної кількості зареєстрованих злочинів склало $20,6 \%$.

У публічних місцях за 9 місяців 2019 року було скоєно 741 кримінальне правопорушення, що становить $4,03 \%$ від загальної кількості вчинених злочинів, з яких було розкрито 325 , тобто $43,9 \%$. Порівняно з аналогічним періодом 2018 року зниження злочинів, скоєних в публічних місцях, становило $41,1 \%$.

3 метою виконання визначених у ст. 2 Закону України «Про Національну поліцію» від 02.07.2015 р. № 580-VIII [2] правоохоронних завдань щодо покращення та забезпечення публічної безпеки і порядку, запобігання правопорушенням та протидії злочинності Головним управлінням Національної поліції в Одеській області вживається та виконується низка організаційних та практичних заходів.

Так, для належного забезпечення публічноїбезпеки і порядку на території Одеської області, попередження та розкриття кримінальних правопорушень, оздоровлення криміногенної обстановки, виявлення осіб, які перебувають у розшуку, незаконно зберігають і перевозять наркотичні речовини та прекурсори, було забезпечене позмінне та цілодобове несення служби працівниками структурних і територіальних підрозділів як Головного управління Національної поліції в Одеській області, так і інших регіональних органів поліції.

Усього до забезпечення публічної безпеки і порядку на території Одеси та Одеської області в середньому щоденно заступає понад 1300 правоохоронців у складі більше 400 нарядів, а саме:

- поліцейські територіальних відділів та відділень поліції (190 працівників);

- працівники групи реагування патрульної поліції (200 працівників);

- поліцейські батальйону поліції особливого призначення (45 працівників);

- поліцейські батальйону патрульної служби поліції особливого призначення «Шторм» (10 працівників);

- поліцейські управління «КОРД» (13 працівників);

- поліцейські Управління патрульної поліції в Одеській області Департаменту патрульної поліції (260 працівників);
- поліцейські Управління поліції охорони в Одеській області (358 працівників);

- військовослужбовці в/ч Національної гвардії України (250 військовослужбовців).

Забезпечення публічної безпеки і порядку, протидії злочинності на території Одеської області є однією із найбільш актуальних проблем, що вирішуються органами поліції. Особливої уваги зазначені питання потребують з урахуванням демографічних, культурних, економічних, адміністративно-територіальних особливостей регіону.

Серед основних факторів, які впливають на загальний стан публічної безпеки і порядку, а також сприяють вчиненню правопорушень та інших суспільно-небезпечних дій, є такі:

- суспільно-політичні (продовження військових дій в окремих районах областей, діяльність окремих політичних сил, які використовують фінансово-економічні проблеми держави для критики влади з метою досягнення протестних настроїв середнаселеннятаневдоволенняурядовихструктур);

- економічні (недостатньо ефективні заходи щодо розвитку виробництва та промисловості, велика кількість збиткових підприємств тощо);

- соціальні (низький рівень заробітної плати, безробіття, недостатня кількість робочих місць для працездатного населення, тіньовий ринок праці, суттєве зростання цін на комунальні послуги, низький показник ефективності системи заходів щодо соціальної адаптації раніше засуджених осіб, які повернулися з місць позбавлення волі);

- культурні (недостатній рівень культури та правосвідомості громадян, що водночас з іншими факторами сприяє поширенню алкоголізму, наркоманії, домашнього насильства, побутових конфліктів) [3].

Ефективність реалізації правоохоронними органами заходів щодо забезпечення публічної безпеки і порядку, протидії злочинності на території Одеської області зумовлена системністю їх проведення на основі детального аналізу криміногенної ситуації та застосування комплексних заходів для вирішення проблемних питань шляхом планування дієвих превентивних та інших заходів.

Досить часто злочинцями, які вчиняють майнові злочини в громадських місцях, є безробітні особи, наркозалежні та особи, які ведуть аморальний спосіб життя, котрі шукають легких способів заробітку за рахунок інших громадян [5]. Найчастіше в публічних місцях злочинці заволодівають золотими виробами, мобільними телефонами, сумками, гаманцями та іншим майном, яке можна без особливих зусиль здати до ломбардів або інших місць скуповування майна [4].

Для запобігання поширенню зазначених правопорушень повинні вживатися такі заходи:

- безперервний моніторинг криміногенної ситуації за рахунок соціологічних технологій 
та забезпечення своєчасного реагування на негативні зміни;

- вивчення міжнародного досвіду превенції правопорушень, протидії злочинності та впровадження його у практичну діяльність правоохоронних органів;

- удосконалення взаємодії органів державної влади, місцевого самоврядування та правоохоронних органів щодо питань забезпечення публічної безпеки та порядку, превенції правопорушень;

- удосконалення науково-методичного, матеріально-технічного та інформаційного забезпечення правоохоронних та інших органів, що беруть участь у забезпеченні публічної безпеки та порядку;

- залучення до організації системи забезпечення публічної безпеки та публічного порядку науковців, представників громадських інститутів, підтримання ініціативи громадян з цих питань;

- проведення профілактичної роботи з керівниками громадських об'єднань з метою попередження радикальних та екстремістських проявів, усунення причин і умов, що сприяють тероризму, екстремізму, роз'яснення руйнівних та негативних наслідків цих проявів;

- здійснення заходів поліцейського піклування, запобігання домашньому насильству, превенція правопорушень на побутовому грунті, на грунті зловживання алкогольними напоями;

- здійснення посиленого контролю за ситуацією у публічних місцях, зокрема при проведенні заходів за участю значної кількості громадян;

- системна реалізація заходів щодо патріотичного, культурного, морального, духовного, спортивного виховання громадян, зокрема дітей, підлітків та молоді, залучення до процесів виховання представників громадськості, підвищення рівня обізнаності щодо заходів особистої безпеки та запобігання правопорушенням [3].

3 огляду на зазначене можна зробити висновок, що сьогодні забезпечення публічної безпеки і порядку, забезпечення безпеки громадян є головними функціями будь-якої держави. Із загальної кількості вчинених злочинів $64,1 \%$ становлять злочини, вчинені на вулицях та в громадських місцях, тому для реалізації комплексу заходів, спрямованих на протидію вчиненню кримінальних правопорушень і забезпечення належного рівня публічного порядку і безпеки громадян, важлива тісна взаємодія усіх підрозділів поліції, основним завданням яких $є$ охорона прав та свобод людини та громадянина. Саме при здійсненні профілактичних та інших оперативних заходів та за підтримки органів державної влади й місцевого самоврядування у особі громадських формувань, які спільно із органами поліції виконують превентивну діяльність з попередження та припинення кримінальних правопорушень у громадських місцях, вдасться стабілізувати криміногенну ситуацію.

\section{Jimepamypa}

1. Про затвердження Положення про порядок ведення Єдиного реєстру досудових розслідувань : Наказ Генеральної прокуратури України від 06.04.2016 p. № 139. URL: https://zakon.rada.gov.ua/laws/show/ z0680-16\#n14.

2. Про Національну поліцію : Закон України від 02.07.2015 № 580-VIII. URL: http://zakon2.rada.gov.ua/ laws/show/580-19.

3. Про затвердження Програми забезпечення публічної безпеки і порядку, протидії злочинності на 2018 рік. URL: https://stsaltiv.gov.ua/storage/ documents/documents/984bd19e89e32a0a8f73411d10 $3 \mathrm{f} 9347$.

4. Головкін Б.М. Злочинність на вулицях та в інших громадських місцях. Питання боротьби зі злочинністю : зб. наук. пр. Харків : Право, 2013. Вип. 26. C. 87-98.

5. Кулик О.Г. Злочинність в Україні на початку XXI століття. Київ : Юрінком Інтер, 2013.

\section{Анотація}

Мусаєва С. С., Заєць О. М. Питання протидії вуличній злочинності та підвищення рівня публічного порядку і безпеки на території Одеської області. - Стаття.

У статті здійснено дослідження та надано поняття вуличної злочинності, охарактеризовано причини та умови, що їй сприяють. Здійснено аналіз об'єктивних та суб'єктивних факторів, що впливають на стан публічної безпеки і порядку на території оперативного обслуговування Одеської області. Наведено статистичні дані, що показують рівень боротьби із вуличною злочинністю на території Одеської області. Виокремлено сили та засоби, які виділяються для забезпечення належного рівня публічної безпеки (кількість працівників правоохоронних органів, які залучаються до щоденної охорони публічного порядку). Зосереджено увагу на пріоритетних завданнях, реалізація яких допоможе зорієнтувати як суспільство, так і правоохоронні органи на більш чітку взаємодію та покращення рівня публічної безпеки і порядку на території оперативного обслуговування. Наведено основні фактори, які негативно впливають на загальний стан публічної безпеки і порядку, а також сприяють вчиненню правопорушень та інших суспільно небезпечних дій. Визначено, що регламентація та реалізація заходів щодо запобігання та протидії вуличній злочинності і забезпечення та підвищення рівня публічної безпеки є вагомою проблемою і потребує негайного вирішення. Протидія вуличній злочинності та забезпечення високого рівня безпеки громадян є пріоритетними напрямами діяльності органів поліції. Зазначено, що на стан публічної безпеки та порядку значно впливає географічне розташування та наявність значної кількості соціально-етнічних меншин, тому поточна криміногенна обстановка на території Одеської області зумовлюється складною політичною, економічною та соціальною ситуацією, яка склалася в нашій державі та у даному регіоні останнім часом.

Ключові слова: публічний порядок, публічна безпека, суспільство, вулична злочинність, профілактика.

\section{Summary}

Musaieva S. S., Zaiets $O$. M. Issues of combating street crime and increasing the level of public order and security in the Odessa region. - Article.

The article investigates and introduces the concept of street crime, describes the reasons and conditions that will prevent them. At the same time, the analysis of objective 
and subjective factors affecting the state of public security and order in the territory of the operational service of the Odessa region is carried out. Provided statistics showing the level of fight against street crime in the Odessa region. The forces and means allocated to ensure an adequate level of public security are highlighted, namely the number of law enforcement agencies involved in the daily protection of public order. The focus is on priority tasks, the realization of which will help focus both society and law enforcement agencies on closer interaction and improvement of public safety and order in the operational service area. The main factors that influence the overall state of public security and order, as well as contribute to the commission of offenses and other socially dangerous actions. At the same time, it was determined that the basic regulation and implementation of measures to prevent and combat street crime and thereby ensure and increase the level of public safety is a major problem and needs immediate solution, where the fight against street crime and ensuring the level of citizens' safety is a priority area of police activity. Thus, it is noted that the state of public security and order is significantly influenced by the geographical location and the presence of a significant number of socio-ethnic minorities, which makes the current criminogenic situation in the territory of Odessa region due to the difficult political, economic and social situation that has developed in our country and the region last years.

Key words: public order, public security, society, street crime, prevention. 